\title{
Women Empowerment in Architectural Research in Tanzania
}

\author{
Huba Nguluma ${ }^{1}$, Isabela Mtani ${ }^{2 *}$ \\ ${ }^{I}$ Graduated as an Architect, Senior Research Fellow in the Institute of Human Settlements Studies at Ardhi \\ University, P.O Box 35124, Dar es Salaam \\ ${ }^{2}$ Graduated as Architect and Research Fellow, P.O Box 35124, Dar es Salaam
}

*Corresponding Author: Isabela Mtani, Graduated as Architect and Research Fellow, P.O Box 35124, Dar es Salaam. Tanzania

\begin{abstract}
This paper examines development of architecture profession worldwide and in Tanzania. It highlights the relationship between research and architecture with main concern on the role of research in the field of architecture and the essence of carrying out architectural research. The challenges faced by female architects in conducting research in the field of architecture are highlighted. The paper concludes by giving the alternative ways of tackling those challenges; and encourage more architects to develop their research skills and suggest that research must come to underpin practice and that a strengthened research culture will extend the area of influence of architects within the community. One of the key recommendations given in this paper is that, Architects need to appreciate that research is important in their field and they should endeavor to participate in carrying out research. Given the nature of their training there is a need to adopt a proactive attitude towards research. Women architects should also strive to work even harder in research and practice despite their productive and reproductive roles.
\end{abstract}

Keywords: Research, Architecture, Women

\section{INTRODUCTION}

Architectural history and theory have roots in academic tradition before the renaissance, a tradition based on reading of texts from antiquity. It was a craft until Alberti developed it into knowledge of formal and aesthetics aspects, so that the craft then became only a tool (Linn Mo, 2002). Alberti in Linn Mo (2002) states that, "A craftsman is merely an instrument of the architect". In the same vein Nicholson (1992) added that the architectural profession came from the master builder informed in the classical styles of architecture, or some dialect of them, to that of master builder capable of delivering a building at a price whose performance equates with the users need.

In the world of building design, the role of women in architecture has been often forgotten. Certainly, male architects have been renown with high-profile buildings. Architecture is a male-dominated field; the most sought after commissions and the highest awards rarely go to women. Nevertheless, many women especially in developed countries have overcome barriers, established highly successful careers, and designed landmark buildings that change the way we see our world.

Women Architects
Zaha Hadid
Born in Baghdad, Iraq in 1950, Zaha Hadid is the first woman to win a Pritzker Architecture
Prize. Her work experiments with new spatial concepts and encompasses all fields of design,
ranging from urban spaces to products and furniture.
Julia Morgan
Julia Morgan designed hundreds of homes, churches, office buildings, hospitals, stores and
educational buildings in California, including the famous Hearst Castle.
Marion Mahony Griffin
Frank Lloyd Wright's first employee was a woman, and she became the world's first woman to be
officially licensed as an architect. Like many other women who design buildings, the Wright's
employee was lost in the shadow of her male associates. Still, it's easy to speculate that Marion
Mahony Griffin contributed greatly to Wright's career and also to the career of her husband,
Walter Burley Griffin

Figure1. Examples of renowned Women Architects in the world

Source: http://architecture.about.com/cs/architectsmasters/a/womenarchitects.htm (17th December 2017) 
Most architectural histories present the architect(s) as the artist(s) and solitary creators, but Woods (1999) trace the history of architects and architecture by describing the early craftsmen, building workshops and craft unions who worked alongside, collaborated with, and competed with professional architects on building projects. She revealed that the architectural profession as it is known and practiced today grew from men trained in building workshops or architectural offices rather than solely through the contribution of professionally trained persons.

The industrial revolution expanded the building market (Nicholson, 1992). It introduced new clientsdevelopers relationship, industrialists, investors in docks, harbors, railways, public corporations and many more. At first the work called only for tradition, craft and skills with which architects were familiar, but as new techniques and materials came into use, a call for engineering design skills came into play in order to fit them into use and called for construction.

Further, the industrial revolution provided new challenges to architects on the type of buildings. Until then Architects were concerned with monumental buildings and high status dwellings only. Improved building technology and new materials means new possibilities. Craftsmen were dying out so architects needed technical solutions. The result was the introduction of architectural field and Architects began to be educated through technical colleges to cope with dramatic changes in science and technology.

Of particular concern is the serious low number of women among architects and under representation of heads of departments, senior management in training institutions in Africa and particularly in Tanzania and among those who access resources from funding agencies and organizations. The underrepresentation of women is also noted in the research community, which has resulted in their limited participation in national discourses and research agendas.

It was noted by Architects and Quantity Surveyors Registration Board (AQRB) of Tanzania that European and Asian dominated the building industry in Tanzania for ten years after independence and the level of education of Tanzanians was very low, which called for introduction of architectural professionals in Tanzania.

University College of Lands and Architectural Studies (UCLAS) which has transformed itself from a Surveying Training Institute (1956 - 1979), Ardhi Institute (1979-1996) and UCLAS (1996 to date) is the first institution to provide architectural education in the Tanzania. It was established after the Government realized the shortage of professionals in land development and the experience gained from the upsurge of technical assistance offered by various donor countries to Tanzania which brought with it many technical personnel including architects. The Department of Architecture was established in 1979, formally known as Building Design and was renamed Architecture in 1983.

Like any other programme, training in building design provided students with practical skills in building design. Later a wider prospective embracing urban design issues were introduced hence the transformation to the discipline of architecture. Until recently in 1990s, students began to learn research methodology and apply the techniques in their final fifth year research projects. The knowledge has eventually helped the graduates in implementing research based architectural projects. However, the number of female students hitherto enrolled in the department of architecture is very low compared to male students as shown in table 1 and 2.

Table1. Enrollment of architecture students from Ardhi University (Bachelor of Architecture (BArch), Bachelor of Science in Landscape Architecture (BSc.LA) and Bachelor of Science in Interior Design (BSc.ID) )

\begin{tabular}{|c|c|c|c|c|c|c|c|c|c|}
\hline \multicolumn{7}{|c|}{ ENROLLEMENT BY PROGRAM } & \multirow{2}{*}{\multicolumn{2}{|c|}{ TOTAL }} & \multirow{3}{*}{$\begin{array}{l}\text { TOTAL } \\
\text { STUDENTS }\end{array}$} \\
\hline & \multicolumn{2}{|c|}{ BARCH } & \multicolumn{2}{|c|}{ LA } & \multicolumn{2}{|l|}{ ID } & & & \\
\hline & $\mathbf{M}$ & $\mathbf{F}$ & $\mathbf{M}$ & $\mathbf{F}$ & $\mathbf{M}$ & $\mathbf{F}$ & $\mathbf{M}$ & $\mathbf{F}$ & \\
\hline 2017/18 & 46 & 13 & 21 & 10 & 18 & 21 & 85 & 44 & 129 \\
\hline 2016/17 & 41 & 19 & 25 & 6 & 13 & 21 & 79 & 46 & 125 \\
\hline 2015/16 & 40 & 11 & 14 & 9 & 18 & 13 & 72 & 33 & 105 \\
\hline 2014/15 & 37 & 9 & 15 & 10 & 18 & 15 & 70 & 34 & 104 \\
\hline 2013/14 & 39 & 24 & 16 & 6 & 8 & 16 & 63 & 46 & 109 \\
\hline 2012/13 & 48 & 15 & 15 & 4 & 5 & 6 & 68 & 25 & 93 \\
\hline 2011/12 & 37 & 24 & 10 & 7 & 12 & 9 & 59 & 40 & 99 \\
\hline
\end{tabular}




\begin{tabular}{|l|l|l|l|l|l|l|l|l|l|}
\hline $\mathbf{2 0 1 0 / 1 1}$ & 258 & 78 & 16 & 3 & 30 & 12 & 304 & 93 & 397 \\
\hline $\mathbf{2 0 0 9 / 1 0}$ & 253 & 43 & 3 & 1 & 18 & 7 & 274 & 51 & 325 \\
\hline $\mathbf{2 0 0 8 / 0 9}$ & 165 & 29 & 2 & 1 & 8 & 1 & 175 & 31 & 206 \\
\hline $\mathbf{2 0 0 7 / 0 8}$ & 157 & 21 & 2 & 1 & 8 & 1 & 167 & 23 & 190 \\
\hline $\mathbf{2 0 0 6 / 0 7}$ & 178 & 20 & & & & & 178 & 20 & 198 \\
\hline
\end{tabular}

Table2. Graduated architecture students from Ardhi University (Bachelor of Architecture (BArch), Bachelor of Science in Landscape Architecture (BSc.LA) and Bachelor of Science in Interior Design (BSc.ID)

\begin{tabular}{|c|c|c|c|c|c|c|c|c|c|}
\hline \multicolumn{7}{|c|}{ GRADUATION BY PROGRAM } & \multirow{2}{*}{\multicolumn{2}{|c|}{ TOTAL }} & \multirow{3}{*}{$\begin{array}{l}\text { TOTAL } \\
\text { STUDENTS }\end{array}$} \\
\hline & \multicolumn{2}{|c|}{ BARCH } & \multicolumn{2}{|c|}{ LA } & \multicolumn{2}{|l|}{ ID } & & & \\
\hline & $\mathbf{M}$ & $\mathbf{F}$ & $\mathbf{M}$ & $\mathbf{F}$ & $\mathbf{M}$ & $\mathbf{F}$ & $\mathbf{M}$ & $\mathbf{F}$ & \\
\hline $2017 / 18$ & 32 & 16 & 3 & 11 & 8 & 4 & 43 & 31 & 148 \\
\hline 2016/17 & 33 & 15 & 8 & 4 & 3 & 11 & 44 & 30 & 74 \\
\hline 2015/16 & 35 & 22 & 14 & 4 & 5 & 5 & 54 & 31 & 85 \\
\hline $2014 / 15$ & 56 & 31 & 6 & 3 & 5 & 8 & 67 & 42 & 109 \\
\hline $2013 / 14$ & 75 & 15 & 11 & 2 & 8 & 3 & 94 & 20 & 114 \\
\hline $2012 / 13$ & 29 & 3 & 0 & 0 & 8 & 5 & 37 & 8 & 45 \\
\hline 2011/12 & 18 & 5 & 0 & 0 & 0 & 1 & 18 & 6 & 24 \\
\hline $2010 / 11$ & 0 & 0 & 2 & 1 & 5 & 0 & 7 & 1 & 8 \\
\hline $2009 / 10$ & 21 & 0 & & & & & 21 & 0 & 21 \\
\hline $2008 / 09$ & 36 & 4 & & & & & 36 & 4 & 40 \\
\hline $2007 / 08$ & 21 & 0 & & & & & 21 & 0 & 21 \\
\hline $2006 / 07$ & 36 & 3 & & & & & 36 & 3 & 39 \\
\hline
\end{tabular}

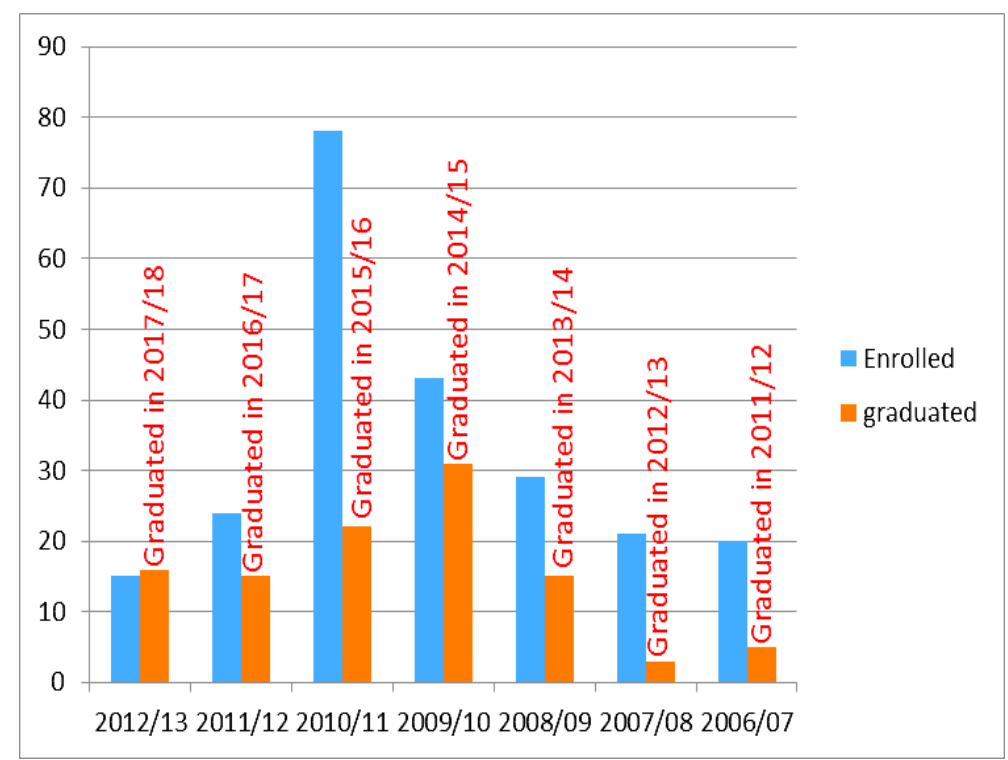

Figure2. Comparison of academic achievements of Female Students in Architecture

Source: ARU facts and Figures (2017)

\section{Methodology}

The study deployed both qualitative and quantitative research approach. Data collection methods used is interviews and literature review. A total number of 20 women Architects were interviewed to give their opinion and views on importance of research in the field of Architecture.

The women were also required to give response on challenges they face in the field of Architecture in relationship to research work. In-depth interviews were also done to individual women Architects who owns architectural firms. Relevant literature was reviewed on renowned women Architects in the world.

\section{RESULTS AND DISCUSSION}

\section{Position of Research in Architecture}

Simon (2001) reveals that since the days of Margaret Thatcher 'research' has been the 'prime directive' for all disciplines in Universities. Nevertheless, during the last twenty years in schools of 
architecture it has often seemed that 'research' can involve anything. However the prime concern is the quality of architectural design.

According to Linn Mo (2001);

"A practitioner calls in a researcher to solve a concrete problem as part of a design or building process. The researcher can feel uncomfortable among the architects because their education sweeps over many subjects in a superficial way. They seem half educated and lack the depth, the critical thinking, and precise use of words and concepts that the researcher expects. Architects are seen as ideological and unsystematic artists. Architects see the researcher as too narrow in knowledge and interest, unable to answer wholistic questions, with an abstract knowledge that is insufficient to solve the concrete problem at hand, or completely useless. The researcher is seen as a producer of analysis and paper, while architect is making a real product"

The history of architecture is carefully documented and analysed. This gives a good indication that the Architecture discipline is research based, as opposed to the way it has been perceived by many architects. Research can make provision of knowledge for example of what is wanted and what is comfortable. Therefore though the architect's creation is a product of imagination, research can provide new ideas, which can assist in solving design problems. There is great expectation of what research can contribute to the discipline of architecture.

There are many research areas which in some way coincide within the realm of building construction and use but most are simply not of interest to architects and many others are of interest on a cyclical basis, depending on shifts in the economic, political and social cultural climate within which building occurs. To date research activities in our country tend to split architecture and building. Most technical research in building materials is done entirely outside of what might be considered architectural practice.

Simon (2001) further highlights that Architectural science and history have long been acknowledged as fields for research, but architectural design, until recently, has been excluded. This has meant that schools of architecture have stretched themselves to continue with teaching design to which they have always been committed, but at the same time tried to build strengths in research areas that, though important, are only supportive or tangential to architectural design itself.

The Tanzania government research institute like National Housing and Building Research Agency (NHBRA), Formally Building Research Unit (BRU) was established in 1971 to provide technical research support to the housing and building industry in Tanzania. This was a positive step towards the development of architectural research in Tanzania as it employed a number of architects who conduct research on its mandatory area.

Apart from BRU, another positive step towards research development in architecture is recruitment and capacity building of Architects in the Institute of Human Settlement Studies (IHSS) at UCLAS. The Institute, core activity is to conduct research in all areas of human settlements. Currently the Institute has Two (2) architects who conduct research in matters related to architecture both of them are women.

Karan et al (2001) defines architectural research as "the search for new knowledge and ideas about building/construction technology, environment behavior studies, history of architecture and/or computer technology". A more generic definition is offered by the International Union of Architects (UIA), who describe research and innovation in architecture as "systematic inquiry, the result of which is new knowledge"

The general direction of architectural research seems to have shifted in the past decade.

As suggested by Groat (2002), throughout this century emphasis within architectural research has shifted, to relate more or less to building technology, socio-behavioral science, design methods, critical methods, energy conservation, more generally to urban social problems and more recently, studies addressing sustainability. The expansion of architectural activities has led to expanded range of professional alliances and publication. Specialized behavioral or social cultural problems also associated with design of certain facilities e.g., health care facilities. Behavior/social scientists, other 
professionals and architects were forced into a closer relationship than previous in the history of the architecture profession. This single mandate alone assisted to contribute to major advance in speculation on the functional relationship between physical environment and behavior, which previously had been less understood by architects.

Maximum feasible participation of community in the design of local projects and in the implementation of programs designed to help them is responsible for massive funding towards support of community organisation activities. This development brought a new dimension in the relationship between architecture and users which has in turn led to research in many subject areas like local construction skills upgrading. There is also a relationship between architecture and urban social problems, which can be solved through architectural research's recommendations to the government and feedback to the society. This will impact knowledge to community and allow for policy changes and/or creation of building regulations and standards.

Environmental issues are equally very crucial in the modern world and call for sustainable solutions in the design of buildings. This creates a room for architectural research to solve the building environmental problems and call for changes in building design, material use and construction techniques. There is also a linkage between disaster management, housing, livelihood and architecture. These calls for architectural research to impact new knowledge to architects, and community as a whole.

Based on the above discussion constant improvement of knowledge must be on every architect's agenda. Thus, if the profession is to meet its responsibilities and societal expectations, beyond the simple exercise of applying skills to a particular project, research is a pre-requisite for the architect's engagement with the broader society.

The growing complexity of the architect's activity is recognized by Groat (2002) as a key reason for architects to be involved in ongoing research. Architectural practice increasingly involves unfamiliar circumstances beyond the expertise of the individual practitioner, and, indeed, beyond the conventional collective wisdom of the profession as a whole. There once was a time when the role and function of architects within the building industry was clearly defined and essentially stable. This time has been replaced by an increasingly complex era of new building types, new building systems and products, new procurement methods, new urban problems, new global environmental issues and concerns. If the architectural profession is to maintain its expertise over the specialist body of knowledge associated with the practice of the profession, then the development of new knowledge, that is, research, is an essential activity to both men and women architects.

The traditional role of architects, which has been tied to technical design expertise, is inadequate to address the changing social, economic and political circumstances in Tanzania. This calls for redefinition of roles of architects and training commensurate with the prevailing circumstances (Nguluma and Lupala, 2000). Architects should be equipped with adequate skills to carry out research. Capacity building of practicing architects to carry out research in their field is of paramount importance in Tanzania. Research is a way of gathering information. Research helps to develop skills and decision-making. If architects need to make good decisions, that are best for the design they make, they need information. By doing research both men and women architects will be in a position to receive advance warning so that they can adjust career decisions and still land on target.

\section{Challenges Facing Women Architect in Carrying Out Research}

Women being treated differently than men begins with early childhood, socialization practices that reinforce different competencies and role expectations for girls and boys. These traditional expectations follow women through the academy into their professional careers.

For many years women did not have access to formal education due to the referred social cultural environment of the time when educating a girl was considered wastage of resources. Tanzanian women were educated to be good wives and mothers in a male dominated society that attended to men needs and careers. Society perceives architecture as men career advising educated girls to choose what they call less masculine careers like Art and Law. In view of this perception, the number of women architect remains low compared to men. According to Yassim at al (2017) "other professionals like lawyers, medics and accountant in UK have managed to achieve $50-50 \%$ participation of both genders and there is no reason why architects in other countries cannot learn from these and other international examples". Tanzania should also learn from these countries. 
Table3. Number of Women Registered Architects in Tanzania, 2017

\begin{tabular}{|l|l|l|l|l|}
\hline \multicolumn{2}{|c|}{ INDIVIDUALS } & \multicolumn{2}{l|}{ PRACTICING FIRMS } \\
\hline TYPE & LOCAL & FOREIGN & LOCAL FIRMS & FOREIGN FIRMS \\
\hline $\begin{array}{l}\text { Total number of Registered } \\
\text { Architects }\end{array}$ & 413 & 34 & 225 & 5 \\
\hline $\begin{array}{l}\text { Total number of Registered } \\
\text { Women Architects }\end{array}$ & 35 & 1 & 12 & - \\
\hline
\end{tabular}

Source: Architects and Quantity Surveyors registration Board (AQRB) (November, 2017)

A Total of 35 registered women architects are practicing as real professionals by providing architectural consulting services. The number for women architect's researchers is even lower. Out of 25 interviewed women architects it is only five (5) of them who are currently engaged in research work, and all of them are from Academic institutions. However, there is no documented data on the current number of women architects who are currently partially or fully involved in architectural research.

"Women are segregated in the tasks they perform, the places they teach,

The fields they occupy, and the ranks they hold. Across each dimension

(task, place, position) women receive lower rewards" (Fox, 1985)

The opportunity of women architects to conduct research can be obtained by:

- Winning and executing a research based project

- Being employed in a research institution

- Being employed in a higher learning institution

- Enrolled in higher education where research is one of the requirement

- Being a PhD. student

Women in Tanzania like any other group in many African societies have predefined activities. Women architects' encounters same challenges as men when practicing in the field of architectural research. The problem is exacerbated for women, because of the conflict, which arises from the time required to accommodate productive and reproductive roles that demands raising children and the need for many hours in fieldwork. This creates a difficult position for women architects to balance, among other things, division of tasks and responsibilities.

More challenges come from lack of resources to conduct research and disseminate research results and inadequate knowledge on scientific research skills.

\section{CONClusion}

In Tanzania architecture research survives as an ad-hoc phenomenon employed only when it is needed. It remains erratic for most subject areas and in general unmonitored and un institutionalized. Research in the field of architecture provides opportunity in linking research knowledge, practice and design. Research is, therefore, fundamental in architecture because it provides knowledge useful for the improvement of architectural issues in the country.

In practice the architect comes out with solutions for the design problem. They are supposed to resolve problems for their clients. There is a need therefore for scientific grounds for how such problems should be handled, and that is research.

Women have proved their ability for design and supervision of construction works, also number of enrolments at the universities in the architecture field has increased as indicated in table 2. However number of women registering practicing firms and working in the architectural profession as architects remains very low as shown in table 3. This is different from the fields of medicine and law where the number of practicing women in those fields is increasing. Women architects who engage themselves in architectural research rarely practice as professionals. This creates a separation between research and practice. It would eventually separate development of new knowledge and dissemination of that knowledge. 
Women Architects have so far reacted with ingenuity to the challenges and difficulties they have faced, making major innovations in the profession by bringing in new knowledge. However, the knowledge these professionals have acquired remains in their hands due to resource constraints to support dissemination of their research findings to the society. The reproductive role has further curtailed their effective participation in architectural research. This is typical of men centered societies where women are marginalized in terms of equitable access to professional fields. Yasmin at al (2007) contends that gender discrimination is an institutional issue rather than personal one, where she further stipulates that "the biased and misogynistic view of architecture persist and that structural change is needed if women are to play a more equitable role"

\section{RECOMMENDATIONS}

- Architects both men and women need to recognize the importance of research in their field and be involved in carrying out research.

- Architects and Quantity Surveyors Registration Board together with Association of Architects in Tanzania should develop and implement a research policy and encourage architects, especially female, to carry out research related to architectural issues.

- Architects be accorded maximum professional freedom with respect to the method of disclosure and publication of their findings.

- There is a need for capacity building for architects, both women and men for training in proposal writing and research methodology.

- Architects and Quantity Surveyors Registration Board should subscribe to journals and periodicals to enable architects keep abreast with new research developments in their areas of specialization.

- Training Institutions need to increase the number of women in undergraduate, postgraduate studies, academia and research.

- There is a great need to encourage and facilitate networks and partnerships among women researchers at local, national and international levels.

- There is a need to monitor the impact of relevant national and institutional policies on funding and other research opportunities for women

- Women architects should lobby, with other partners, for policies and strategies that enable them to participate actively in the research domain.

\section{REFERENCES}

[1] Ahrentzen, S., Betrabet, G., Dally Geboy, L., and Dearborn-Karan, L., (2001), “Architectural Research Methods Training in Education and Practice"

[2] ARU (2006), "Facts and Figures", Ardhi University, Dar es Salaam, Tanzania.

[3] Fox M.F (1995), "Women and Higher Education: A Feminist Perspectives", In J. Freeman, Mountain View CA: Mayfield.

[4] Groat, L. \& Wang, D. (2002), “Architectural Research Methods”. New York: John Wiley and Sons.

http:// www.scotishArchitecture.com:3000/article/view/hmtl, website visited on 07 March,2017

[5] Linn Mo (2002), "Philosophy of Science for Architects", NTNU

[6] Nguluma, H., Lupala, J. (2000), "The Role of Physical Planning for Addressing the Problems of Informal Settlements In Tanzania”, Stockholm, Sweden.

[7] Nicholson, M. P (1992), "Architectural Management" Great Britain University Press: Cambridge, London.

[8] Simon U. (2001), “Architecture in Detail” in www.scotishArchitecture.com:3000/article/view/hmtl

[9] UCLAS (2006), "Facts and Figures", University College of Lands and Architectural Studies, Dar es Salaam, Tanzania.

[10] Woods, N. M (1999), "from craft to profession: the practice of Architecture in nineteenth-century America" Berkeley, CA: University of Califonia Press.

[11] Yasmin, S., Eva, A., and Carlos, G. (2017): Women in architecture. A paper presented in UIA 2017 Seoul world Architects Congress 


\section{AUTHOR'S BIOGRAPHY}

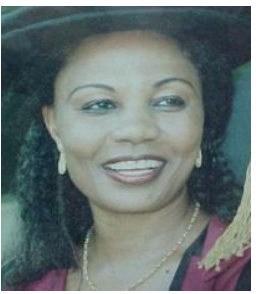

Dr. Huba M. Nguluma, received the PhD. Degree in Built Environment Analysis in 2003 from Royal Institute of Technology, Stockholm, Sweden. She is an architect and a Senior Research Fellow with the Institute of Human Settlements Studies of the Ardhi University where she has been employed since 1993. Dr. Nguluma used to work with the Building Research Unit of the then Ministry of Lands and Human Settlements as a Research Architect from 1986 to 1993. Dr. Nguluma also lectures and supervises postgraduate and undergraduate students in the school of Architecture, Construction Economics and Management (SACEM), School of Spatial Planning and Social Sciences (SSPSS) and Institute of Human Settlements (IHSS) at Ardhi University. Her major fields of specialization are Architecture, Built Environment and Housing. Dr. Huba Nguluma has carried out a number of research and consultancies in the field of Architecture and Human settlements. She is also a Registered Architect with the Board of Architects and Quantity Surveyors (AQRB) and a member of Architects Association of Tanzania (AAT)

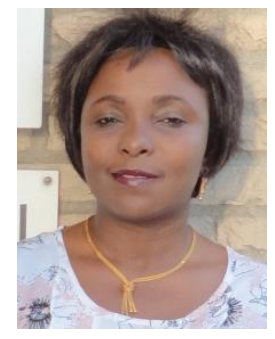

Dr. Isabela Wilfred Mtani, is a registered architect since 2007 by the Architect and Quantity Surveyors Registration Board (AQRB), Deputy secretary of Architects Association of Tanzania (AAT) and member of the Arbitration Institute of Tanzania. She is employed as Research Fellow at the Institute of Human Settlement Studies and acting director of Gender Dimension Unit of the Ardhi University in Dar es Salaam, Tanzania. She holds a Bachelor of Architecture from the University of Dar es Salaam, 2001, Master of Engineering Management (MEM) specializing in Project Management from the University of Dar es Salaam, 2004, Advance diploma in management and conservation of historic building from Lund University in Sweden, 2008 and PhD in Engineering specializing in building material science from Kassel University in Germany in 2014. Dr. Mtani lectures and supervise students in school of architecture, construction economics and management (SACEM) and Institute of Human Settlement Studies (IHSS) at the Ardhi University. She specialized in architecture, building materials, conservation and management of historic buildings and housing.

Citation: Huba Nguluma, Isabela Mtani. "Women Empowerment in Architectural Research in Tanzania". International Journal of Humanities Social Sciences and Education (IJHSSE), vol 5, no. 2, 2018, pp. 27-34 doi: http://dx.doi.org/10.20431/2349-0381.0502004.

Copyright: (9) 2018 Authors. This is an open-access article distributed under the terms of the Creative Commons Attribution License, which permits unrestricted use, distribution, and reproduction in any medium, provided the original author and source are credited. 